\title{
Statistical Interpretation and Profiling the Leaching Characteristic of Chromium in the Basic Chrome Sulphate (BCS) Sludge Dumping at Village Khanchandpur-Rania, District Kanpur Dehat, Uttar Pradesh (India)
}

\section{Vinod Kumar}

Babu Banarasi Das University

Pokhraj Sahu

Bharat Oil and Waste Management Ltd

Richa Singh

Babu Banarasi Das University

Arti Gupta

Babu Banarasi Das University

Pramod Kumar Singh ( $\nabla$ singh_p_kumar@rediffmail.com )

Babu Banarasi Das University

\section{Research Article}

Keywords: Hazardous waste, dumping site, BCS sludge, hexavalent Cr, TCLP

Posted Date: November 29th, 2021

DOl: https://doi.org/10.21203/rs.3.rs-584387/v1

License: (c) (1) This work is licensed under a Creative Commons Attribution 4.0 International License. Read Full License 


\section{Abstract}

Without immobilized hazardous waste contaminates soil and groundwater, which can further bioaccumulates and poses serious negative health impact on flora as well as fauna. The present investigation has been conducted to study of leaching behavior of chromium species in immobilized hazardous waste containing Basic Chrome Sulphate (BCS) dumped at dumping site Khanchandpur Kharanja, Rania, Kanpur Dehat district of Uttar Pradesh, India. Results indicated that the $\mathrm{pH}$ of sludge ranged from 10.16-11.90 while EC ranged from $840-16160 \mathrm{dSm}^{-1}$ in a different layer of the dumpsite and significantly varies on increasing depth. A similar trend was also observed in TDS contents which strongly justified the leaching of salts in lower depth. Total Cr concentration (25029.94 $\left.\mathrm{mg} \mathrm{kg}^{-1}\right)$ was observed in the top layer which was significantly increased on increasing depth i.e., $36102.0 \mathrm{mg} \mathrm{kg}^{-1}$ and $42811.77 \mathrm{mg} \mathrm{kg}^{-1}$ while TCLP based concentration ( $216.44 \mathrm{mg} \mathrm{kg}^{-1}$ in top layer) was significantly increased on increasing depth i.e., $406.25 \mathrm{mg} \mathrm{kg}^{-1}$ and $517.60 \mathrm{mg} \mathrm{kg}^{-1}$. A similar trend was also observed in total and TCLP hexavalent and trivalent $\left(\mathrm{Cr}^{6+}\right.$ and $\left.\mathrm{Cr}^{3+}\right)$ chromium concentration. Hierarchical Cluster Analysis is separated all sample based on depth into three different cluster based on dissimilarity. A significant correlation was observed with TCLP $\mathrm{Cr}^{6+}$ in $\mathrm{TCLP} \mathrm{Cr}^{3+}, \mathrm{EC}$, and TDS at 0.01 levels while EC, TDS, total $\mathrm{Cr}^{6+}$, and TCLP Cr were significant correlated with $\mathrm{TCLP} \mathrm{Cr}^{3+}$. The leaching behavior of $\mathrm{Cr}$ species was higher as well as increasing of depth in the dumping site.

\section{Introduction}

The rapid industrialization of India led to a geometrical rise in the level of air, water, and land pollution. Chromium is considered an environmentally hazardous element and classified as a class-A human carcinogen. Chromium is a naturally occurring element present in water, sediments, rocks, soils, plants, biota, animals, and volcanic emissions under various chemical, physical, and morphological forms (Siraj et al. 2012) which exist in several oxidation states (0-6). Only two of them, the $\mathrm{Cr}^{3+}$ and $\mathrm{Cr}^{6+}$ are stable and enough to occur in the environment (Ducros 1992; Shriver et al.1994), which differs from one another in charge, physicochemical properties as well as chemical and biological activities. Hexavalent chromium in the form of water-soluble complex anions in surface water undergoes reduction to $\mathrm{Cr}^{3+}$ possessing a much shorter lifetime (Callahan et al. 1979). $\mathrm{Cr}^{6+}$ may exist in three different ionic forms in a solution: hydro chromate $\left(\mathrm{HCrO}_{4}^{-}\right)$, chromate $\left(\mathrm{CrO}_{4}{ }^{2-}\right)$, and dichromate $\left(\mathrm{Cr}_{2} \mathrm{O}_{7}{ }^{2-}\right)$. Although the chromate ion predominates in both basic and neutral media, the hydro-chromium predominates in solutions of lower pHs indicating the pH dependence of the proportion (Dhungana et al. 2009; Nriagu and Nieboer 1988; USEPA 1998; EPA 1984).

Industrial applications of $\mathrm{Cr}$ include electroplating, pigment production, leather tanning (Fishbein 1971), and controlling biofilms in cooling towers (Lund 1971). Inadequate storage and improper disposal practices of $\mathrm{Cr}$ have caused incidents of soil and groundwater contamination in many areas (Nriagu \& Nieboer 1988; Palmer and Wittbrodt, 1991). Once chromium enters the environment, it exists in the two most stable oxidation states i.e., $\mathrm{Cr}^{3+}$ and $\mathrm{Cr}^{6+}$ (Bartlett 1991). Among these trivalent form of chromium is 
comparatively offensive and nearly immobile, while hexavalent chromium moves rapidly through soil and water. This form of chromium generally acts as an irritant to plant and animal tissues and carcinogenic (Nieboer \& Jusys 1988). $\mathrm{Cr}^{3+}$ occurs primarily as a cation in solution and forms complexes with inorganic and organic ligands (Hartford 1979). It is considered an essential trace nutrient for animals and humans (Anderson 1993; Richard \& Bourg 1991). $\mathrm{Cr}^{6+}$ can be toxic to bacteria, plants, and animals (Anderson, 1995; Kimbrough 1999). The use of chromium and chromium compounds is increase due to fast growth through intensive industrialization. In the metallurgical industry, it is used for the manufacture of various alloys and steel. Chromate ore is also extensively used in making refractory materials like bricks. Chromate is used in the chemical industry to make many chromium-containing chemicals. Chromium compounds are used in electroplating, tanneries catalysts, pigments, wood preservatives, and corrosion inhibitors (Dhal et al. 2013).

A detailed investigation about the status of hexavalent chromium was undertaken by CPCB and CGWB in the area of sludge dump at village Umran (Singh et al. 2013), Rania - Jainpur area in Kanpur Dehat, UP, India where had long-standing problem due to indiscriminate disposal of high concentration chromium bearing Basic chromium sulfate (BCS) sludge by BCS units and also due to improper drainage in the area (Singh et al. 2013). BCS used in leather tanning processes is not completely taken up by the hides and skins. Its uptake is limited to $55-70 \%$, and the remaining portion is discharged as waste. Therefore, about $40 \%$ of the $\mathrm{Cr}$ amount remains in the solid and liquid wastes especially spent tanning solutions (Covington \& Sykes 1983; Silveira et al. 2006). The presence of $\mathrm{Cr}^{3+}$ and its salts in the sludge of both the wastewater biological treatment plants or the chemical plants for recycling spent tanning liquors represents an inconvenience for the safe reuse of these sludge and a cost forming factor for their disposal as well as a real threat to the environment. Also, tanneries are doing illegal dumping of wastewater and sludge that causes serious environmental pollution. Tanning is one of the oldest and fastest-growing industries in India. There are about 2,000 tanneries located at different centers with a total processing capacity of 600,000 tons of hides and skins per year as per observed by Raju and Tandon (1999). Two major sources of Cr contamination are sludge-treated/amended soil (Dreiss 1986) and uncontrolled disposal of wastes (Makdisi 1991).

According to the inventory of the Central Pollution Control Board (CPCB) as of 2015 , the total chromiumcontaining waste illegally dump in various Indian City is about 430960 MT and out of this 70000 MT waste is still dumped in Kanpur Uttar Pradesh at three different sites one of them is most polluted chromium ( $\mathrm{Cr}$ ) containing hazardous waste dumped at Khanchandpur, Rania, Kanpur Dehat (U.P.) since 1976 as Basic Chrome Sulphate Sludge (BCS). Although responsible polluter industries were also notified by Uttar Pradesh Pollution Control Board and CPCB, the dumpsite was closed in 2005 by the Government of India. Matern et al. 2020 studied the column experiment and modeling to identify the leaching characteristic of chromium (VI) in the young chromite ore residue. Researchers reported the Level of chromium (VI) in ground water of Raniya area in District Kanpur Dehat (Singh et al 2013; Matern et al. 2017). In the present study, profiling of chromium in the BCS sludge sample collected from dumping site of hazardous waste to assess the total concentration of chromium and its different oxidation species. It 
was also assessed the leachability of different chromium oxidation states e.g., chromium, chromium trivalent $\left(\mathrm{Cr}^{3+}\right)$, chromium hexavalent $\left(\mathrm{Cr}^{6+}\right)$, and comparative study of total and TCLP based concentration. As Concern of Chemicals (CoCs) chromium metal profiling was needed for preparing the remedial action. Different statistical tools were executed to interpret the finding and correlate them.

\section{Materials And Methods}

\section{Study Area of Dump Site}

The sample was collect from the unlined/ illegal waste dumpsite of Chromium bearing Hazardous Waste, which was situated at 26ه24'57" NL and 80ه3'28" EL at Khanchandpur Kharanja, Rania, Kanpur Dehat district of Uttar Pradesh, India (Fig. 1). The area of the dumpsite was 30000 to $35000 \mathrm{~m} 2$ and the quantity had 63000 MT of waste as per Central Pollution Control Board (CPCB) inventory which was classified under schedule-II of Hazardous and Other Wastes. The dumpsite area has a huge stockpile of chromium-containing sludge which had generated by the local industries engaged in manufacturing Basic Chrome Sulphate (BCS) and under the consideration of the prevailing manufacturing practices adopted by BCS manufacturing units in the area and their role in causing pollution of groundwater. At this dumping site i.e., Khanchandpur, Rania, Kanpur Dehat (U.P.) dump Basic Chrome Sulphate Sludge (BCS) since 197. Although responsible polluter industries were also notified by Uttar Pradesh Pollution Control Board and CPCB, the dumpsite was closed in 2005 by the Government of India.

Kanpur Dehat district having an area of about 3021 square kilometers and the dumpsite located at RaniaKhanchandpur also known as Khanchandpur kharanja near NH-2 Toll Plaza $10 \mathrm{~km}$ east from the main dense populated city was Akbarpur which was approximately $20 \mathrm{~km}$ west side from Kanpur city.

According to the 2011 census, the Kanpur Dehat district has a total population was 1,795,092. Kanpur Dehat district of Uttar Pradesh state in northern India and the administrative headquarters of the district are at Mati-Akbarpur. This district was part of the Kanpur division.

\section{Sample Collection}

For sampling of hazardous waste standard methods was followed by CPCB manuals 2011. The samples were collected in polythene bags and transported to the laboratory after appropriate labeling for further analysis. A total of twenty-seven (27) samples were collected from nine places up to $150 \mathrm{~cm}$ depth and these depths were divided as D1:Top layer $(0-15 \mathrm{~cm})$, D2: Subsurface layer $(15-75 \mathrm{~cm})$, and D3: Lower depth $(75-150 \mathrm{~cm})$ in three vertical strata of the dumpsite. The personnel protective equipment was used during the collecting of samples. The sample was collected into the clean and air tight polybag which was air dry in the laboratory. After the air-drying sample was crushed through the porcelain motor and then sieved with a $10 \mathrm{~mm}$ sieve. The samples were analyzed for the TCLP extraction method and total concentration of chromium oxide including bulk density (BD), pH, EC, and TDS.

\section{TCLP Extraction based determination of chromium species}


TCLP designed to determine the mobility of both organic and inorganic analytes present in liquid, solid, and multiphasic wastes which is chemical analysis process used to determine whether there are hazardous elements present in a waste. The test involves a simulation of leaching through a landfill and can provide a rating that can prove if the waste is dangerous to the environment or not. This rating can dictate the waste management methodology that should be adopts to dispose of the waste afterward. For the TCLP extraction, the test procedure was adopted as mentioned in USEPA SW-846 Test Method 1311: Toxicity Characteristic Leaching Procedure. Weight accurately $25.0 \mathrm{gm}$ prepared test sample and slowly add $500 \mathrm{ml}$ of extraction fluid which is prepared by dilute $5.7 \mathrm{~mL}$ glacial $\mathrm{CH} 3 \mathrm{CH} 2 \mathrm{OOH}$ with reagent water to a volume of 1 liter. When correctly prepared, the $\mathrm{pH}$ of this fluid will be $2.88+0.05$ to the extractor vessel. Close the extractor bottle tightly, secure in rotary agitation device, and rotate it at $30 \pm 2 \mathrm{rpm}$ for 18 \pm 2 hours. As define in Hazardous and Other Wastes (Management and Transboundary Movement) Rules, 2016 schedule-II note three, Cr6 + extractions was done using distilled water in place of the leaching media specified in the TCLP procedures. The leachable Total chromium concentration measured followed by Atomic absorption spectrophotometer make "analytical jena novAA-350" and hexavalent chromium was measured by spectrophotometer make Systronics-108.

\section{Determination of total chromium hexavalent}

$2.5 \mathrm{gm}$ of the moist sample was taken in a cleaned and labeled $250 \mathrm{ml}$ beaker and added $50 \mathrm{ml}$ digestion solution (20.0 $\pm 0.05 \mathrm{gm}$ Sodium hydroxide, $30.0 \mathrm{gm} \pm 0.05$ Sodium carbonate dissolve in $1000 \mathrm{ml}$ distilled water). $392.18 \mathrm{mg} \mathrm{MgCl}$ and $0.5 \mathrm{ml}$ of $1.0 \mathrm{M}$ phosphate buffer were added to the beaker and allow to stirrer without heat for at least $5 \mathrm{~m}$ by using a stirring bar. The sample was heated and maintains the temperature between $90-95^{\circ} \mathrm{C}$ with constant stirring for 60 minutes and cover all samples with a watch glass. Gradually allow cooling down each solution at room temperature, filtering the all solutions by using Whatman filter paper $(0.45 \mu \mathrm{m})$ and rinses to clean the $250 \mathrm{ml}$ beaker and again place a magnetic stirrer into digested sample beaker and added the concentrated nitric acid solution drop wise with constant stirring. Adjust the $\mathrm{pH} 7.5 \pm 0.5$. Transfer quantitatively the content of the beaker to a 100 $\mathrm{ml}$ volumetric flask and make up the volume with double distilled water. The digested sample ready for analysis. $95 \mathrm{ml}$ of the extract was transferred into a $100-\mathrm{mL}$ volumetric flask. Diphenylcarbazide solution $(2.0 \mathrm{~mL})$ was added and mix properly. The $\mathrm{pH}$ was maintained upto $2 \pm 0.5$ by adding $\mathrm{H}_{2} \mathrm{SO}_{4}$ solution and then volume was make up $100 \mathrm{~mL}$ with reagent water. Within 5 to 10 minutes full-color was developed. Simultaneously blank was also run with distilled water for blank correction. Absorbance was measured at $540 \mathrm{~nm}$ by UV-spectrophotometer (make- systronics-108). Chromium was determined from the reference calibration curve.

\section{Determination of $\mathrm{pH}, \mathrm{EC} \&$ TDS}

For the characterization of the physical property i.e., bulk density (BD), $\mathrm{pH}, \mathrm{EC}$, and TDS were assessed by adopting standard methods USEPA SW-846; 9045D, $20 \mathrm{~g}$ of soil sample was taken in a 50-mL beaker and added $20 \mathrm{~mL}$ of double-distilled water, cover, and continuously stir the suspension for $5 \mathrm{~min}$ by stirrer. Additional dilutions were allowed if working with hygroscopic soils and salts or other problematic matrices. Let the soil suspension stand for about $1 \mathrm{hr}$ to allow most of the suspended clay to settle down 
from the suspension or filter or centrifuge off the aqueous phase for $\mathrm{pH}$ measurement, the same aliquot is also used for measurement of electrical conductivity (EC) as well as TDS by gravimetric method.

\section{Digestion of sample for total chromium analysis}

The processed sludge sample was digested by nitric/hydrochloric acid digestion followed by metal analysis (SW 846 US EPA method 3050B). $2.0 \mathrm{~g}$ of samples was digested in $10 \mathrm{~mL} \mathrm{HNO}$ (1:1) by heating $95^{\circ} \mathrm{C}$ up to 15 minutes. $5 \mathrm{~mL} \mathrm{HNO}_{3}$ added after cooling. Chromium was extracted from solid samples by covering the beaker with a watch glass and refluxing the sample in the dilute acid mixture for 30 minutes. After extraction, extract was diluted to specify volumes with reagent water, mixed and either centrifuged or allowed to settle overnight before analysis. Diluted samples were to be analyzed by atomic absorption spectrometer (AAS) methods as soon as possible after digestion completed.

\section{Statistical analysis}

The SPSS software was used for the interpretation of descriptive statistics (Mean and SEM), Bivariates analysis of variance, LSD Post hoc test, Hierarchical cluster analysis (HCA), and Pearson correlation analysis.

\section{Bivariates analysis of variance}

The analysis of variance (ANOVA) was performed in the data set for comparing the mean and relative difference in the data set. It was a parametric statistical solution to find out a significant difference in the individual and dependent variables. ANOVA has been performed in several ways but, It has three types namely univariate (One-way), bivariates (Two-way), and multivariates (K-way) analysis of variance. The univariate ANOVA test analyzing the group of data by using only one variable from the group. A variable is just a conditioned or subset that the groups of data fall into if the variables have more than one at a time it is called bivariates and variables further increase up to three or more it is called multivariate ANOVA (Gagné 2014). The bivariates analysis of variance (ANOVA) was performed in the SPSS software against the concentration of hexavalent and total chromium in TCLP extract of BCR sludge sample collected from deferent depth. In which is further multi comparison test conducted by Post hoc test.

\section{Hierarchical cluster analysis (HCA)}

The HCA is a useful technique for visual comparison in the data; it builds a tree plot where data participated within branches that are close together and dissimilar data separated in other branches (Sahu et al. 2018). The HCA was performed in the SPSS software against the physicochemical data of BCR sludge sample collected from the deferent depth the Linkage algorithm applied through ward linkage and distance was measured through rescaled distance cluster.

\section{Pearson Correlation analysis}

The correlation matrix is a Statistical tool to finding the relationship between data sets is significant or not at 0.01 and 0.05 level (Kumar et al. 2020; Singh et al. 2021). The correlation was analyzed in the physicochemical data sets of BCS sludge. 


\section{Results And Discussions}

Chromium profiling was done from the unlined/ illegal waste dumpsite of Chromium bearing Hazardous Waste, which was situated at 26ه 24'57" NL \& 80区 3'28" EL in Khanchandpur Kharanja, Rania, Kanpur Dehat, district of Uttar Pradesh, India. Basic Chrome Sulphate Sludge (BCS) was dumped in 1976. Different industries were responsible for generating $\mathrm{Cr}$ containing hazardous wastes which were also dumped and stored since 1976 and were closed in 2005. Now it was prohibited by the pollution control board to dump any kind of waste materials at the said dump site, so it was almost closed. A similar case was also found in Tamil Nadu. The Tamil Nadu Pollution Control Board (TNPCB) estimates that about 150,000 tons of solid wastes accumulated over two decades of plant operation were stacked in an open yard (three to five meters high and on 2 hectares of land) on the facility premises. It is common conception nowadays that the total concentrations of metals in soils are not a good indicator of phytoavailability, or a good tool for potential risk assessment, due to the different and complex distribution patterns of metals among various chemical species or solid phases (Silveira et al. 2006; Tessier et al. 1979; Elzinga and Cirmo 2010). Hence, in 1995, the Supreme Court of India ordered the closure of hundreds of tanneries in Tamil Nadu for failing to treat their effluents (Kennedy 1991).

\section{Characterization of dumping site sludge}

Results indicated that the $\mathrm{pH}$ of BCS sludge ranged from 10.16-11.90 which were significantly varied and shows alkali in nature (Table-1). Maximum pH was observed in the middle of the dumpsite in different depths while the least $\mathrm{pH}$ was observed towards the $\mathrm{NH} 2(\mathrm{~L}-1)$. $\mathrm{pH}$ significantly increased on increasing depth which may be due to leaching of salts in lower depth. A similar finding was also observed by other worker and stated that chromites ore processing residue(CORP) contains un-reacted chromites ore as well as residual (i.e., non-extracted) $\mathrm{CrO}_{4}{ }^{2-}$. COPR is strongly alkaline, with $\mathrm{pH}$ values typically between 11.0 and 12.5 (Chrysochoou et al. 2009; Deakin et al. 2001b ; Földi et al. 2013). These statements had also justified with the results of EC which indicated that EC of sludge ranged from 840$16160 \mathrm{dSm}^{-1}$ in a different layer of BCS dumpsite and significantly varies on increasing depth (Table 1). The mean values of EC significantly increased on increasing depth due to leaching of salts in lower depth. Least EC at surface layer $\left(935 \mathrm{dSm}^{-1}\right)$ while maximum in lower depth $\left(3103.3 \mathrm{dSm}^{-1}\right)$. A similar trend was also observed in TDS contents which strongly justified the finding. While bulk density was nonsignificant variation was observed. Geelhoed et al. 2002 reported that during leaching, the $\mathrm{pH}$ decreased moderately from 12.3 to 11.7 (Rania COPR) and 12.6 to 12.1 (Chhiwali COPR). Considering that COPR has a high buffer capacity that alkaline $\mathrm{pH}$ values will prevail in the seepage water of COPR dumps in the next decades.

\section{Total chromium and its different oxidation species}

The BCS sludge from the dumping site indicated that the least concentration of total $\mathrm{Cr}$ was observed in the top layer which was significantly increased on increasing depth. The mean value of total $\mathrm{Cr}$ concentration was $26208.33 \mathrm{mg} \mathrm{kg}^{-1}$ in the top layer which was significantly increased $36102.0 \mathrm{mg} \mathrm{kg}^{-1}$ 
and $42811.77 \mathrm{mg} \mathrm{kg}^{-1}$ in the subsurface and the depth respectively (Fig. 2a). If we observe location-wise then the maximum concentration in the top layer was observed in the middle of the dumpsite while least concentration (25029.94 $\mathrm{mg} \mathrm{kg}^{-1}$ ) in hind or towards village side of the top layer while in the subsurface layer it was observed least towards NH24 highway (34308.46 mg kg-1) and maximum (39482.59 mg kg-1) towards village side of dumpsite (Table 1). This variability in the concentration of total $\mathrm{Cr}$ at a different location in different depths may be due to the leachability of total $\mathrm{Cr}$ as per time duration and depth. But overall average mean values indicated that total $\mathrm{Cr}$ concentration increased significantly on increasing depth (Fig. 2a).

Total $\mathrm{Cr}^{6+}$ showed a similar trend as observed in total $\mathrm{Cr}$ concentration which was significantly decreased on increasing depth at all locations. The average mean concentration was indicated that $9653.16 \mathrm{mg} \mathrm{kg}^{-}$ $1,24393.93 \mathrm{mg} \mathrm{kg}^{-1}$, and $24946.88 \mathrm{mg} \mathrm{kg}^{-1}$ in the upper layer, subsurface, and depth respectively (Table 1\& Fig. 2b) which showed minimum concentration in the top layer and maximum total $\mathrm{Cr}^{6+}$ concentration in depth. There were insignificant changes were observed in between subsurface and lower depth that may be due to either hindered rate of leaching of total $\mathrm{Cr} \mathrm{Cr}^{6+}$ on increasing depth (Fig. 2b).

The mean concentration of total $\mathrm{Cr}^{3+}$ was indicated as $8951.24 \mathrm{mg} \mathrm{kg}^{-1}, 16560.96 \mathrm{mg} \mathrm{kg}^{-1}$, and 20615.80 $\mathrm{mg} \mathrm{kg}^{-1}$ in the upper layer, subsurface, and lower depth respectively which was significantly increased on increasing depth (Table 1\& Fig. 2c)). Total $\mathrm{Cr}^{3+}$ showed similar trends as observed in total $\mathrm{Cr}$ and $\mathrm{Cr}^{6+}$ concentrations which were significantly decreased on increasing depth at all locations. If we thoroughly observed location-wise concentration of total $\mathrm{Cr}+3$ then the least concentrated in the upper layer was observed towards $\mathrm{NH}-2$ of dumping site which was significantly increased towards the middle (L2) and village site (L3). This may be due to the time duration that $\mathrm{Cr}^{3+}$ vertically moves downwards in earlier dumping hazardous waste (Table 1\& Fig. 2c) i.e., towards NH2. A similar finding was also reported in which $\mathrm{Cr}$ concentration ranging between 2000 and $5000 \mathrm{mg} / \mathrm{L}$ in the aqueous effluent from the tanning industries which was very high than the recommended permissible limit of $2 \mathrm{mg} / \mathrm{L}$ while $0.05 \mathrm{mg} / \mathrm{L}$ in drinking water( Mohan 2006). Singh et al. 2013 studied a detailed investigation about the status of hexavalent chromium in the area of sludge dump at village Umran, Rania - Jainpur area in Kanpur Dehat, UP, India where had long-standing problem due to indiscriminate disposal of high concentration chromium bearing BCS sludge and also due to improper drainage in the area. They observed that the quality of groundwater in bordering stockpiles and nearby villages was badly affected by hexavalent chromium $(80 \mathrm{mg} / \mathrm{L})$ while BIS permissible limit is up to $0.05 \mathrm{mg} / \mathrm{L}$. They marked the entire area alarming high concentration of $\mathrm{Cr}$ which was imparted strong pale yellow color to groundwater. Wang et al. 2004 reported that correlation was better between plant growth and available $\mathrm{Cr}$ than between plant growth and total $\mathrm{Cr}$. It has long been recognized that the soluble, exchangeable, and loosely adsorbed metals are quite labile and hence more bioavailable for plants (Cary et al. 1977; Lasat 2004). Also, clayey soil might have high sorption capacity for $\mathrm{Cr}$ than other types of soils (Adriano 1986). Pendias and Pendias 1992 considered $75-100 \mathrm{mg} / \mathrm{kg}$ as a critical value/load for chromium in soils. The concentration in the lowest soil horizon is commonly used to represent the natural background value, which is representative of the individual soil profile (Blaser 2000). Mandal et al. 2011 reported total $\mathrm{Cr}$ in sludge samples collected from 
the dumping site contained 377-1052 $\mu \mathrm{g} \mathrm{Cr} / \mathrm{g}$ sludge( acid digestion), whereas 413-1213 $\mu \mathrm{g} \mathrm{Cr} / \mathrm{g}$ sludge( microwave digestion), whereas sludge samples collected from the tannery contained 492-2941 $\mu \mathrm{g} \mathrm{Cr} / \mathrm{g}$ sludge (acid digestion), whereas 490-3540 $\mu \mathrm{g} \mathrm{Cr} / \mathrm{g}$ sludge ( microwave digestion). So, proper treatment and disposal of sludge in stockpile on priority have required simultaneously techno-feasibility must be explored for chemical treatment (immobilization) of chromium bearing sludge and its judicious disposal must be required.

\section{TCLP based concentration of $\mathrm{Cr}$ and its different oxidation species}

TCLP or Toxicity Characteristic Leaching Procedure is a chemical analysis process used to determine whether there are hazardous elements present in the waste. The test involves a simulation of leaching through a landfill and can provide a rating that can prove if the waste is dangerous to the environment or not. This rating can dictate the waste management methodology that the company adopts to dispose of the waste afterward. In the present study TCLP based concentration of $\mathrm{Cr}$ and its different oxidation species were assessed. Results indicated that TCLP based concentration of $\mathrm{Cr}$ was very high in all locations which was significantly increased on increasing the depth of the dumping site. In the top layer, it was ranged from $126.32-294.64 \mathrm{mg} \mathrm{kg}^{-1}$ with an average mean value of $216.44 \mathrm{mg} \mathrm{kg}^{-1}$ which was significantly increased on increasing depth i.e., $406.25 \mathrm{mg} \mathrm{kg}^{-1}$ and $517.60 \mathrm{mg} \mathrm{kg}^{-1}$ in the subsurface and lower depth respectively (Table 1\& Fig. $2 \mathrm{~d}$ ). These values of TCLP based $\mathrm{Cr}$ were manifold higher than the permissible limit. The same trend was also observed in the case of TCLP based $\mathrm{Cr}^{6+}$ and $\mathrm{Cr}^{3+}$ which concentration was observed minimum in the top layer (mean $108.43 \mathrm{mg} \mathrm{kg}^{-1}$ and $100.31 \mathrm{mg} \mathrm{kg}^{-1}$ respectively) and further these were significantly increased on increasing depth i.e., $153.06 \mathrm{mg} \mathrm{kg}^{-1}$ and $230.35 \mathrm{mg} \mathrm{kg}^{-1}$ respectively in subsurface layer while $198.47 \mathrm{mg} \mathrm{kg}^{-1}$ and $352.99 \mathrm{mg} \mathrm{kg}^{-1}$ respectively in the lower depth of dumping site (Table 1 \& Fig. 2e \& 2f).

\section{Statistical Analysis}

Profiling of different oxidation states of chromium was executed in the different depth of dumped hazardous waste and following statistical interpretation conducted on the analyzed data.

\section{Analysis of variance}

In this study, the Bivariates analysis of variance had performed in SPSS software to identifying the leaching characteristic of chromium species in different depth i.e., the top layer $(0-15 \mathrm{~cm})$, subsurface layer $(15-75 \mathrm{~cm})$, and lower depth $(75-150 \mathrm{~cm})$ at dumping site through comparing the mean concentration of $\mathrm{Cr}^{6+} \&$ total $\mathrm{Cr}$ shown in Table 2. In this group of data chromium species $\left(\mathrm{Cr}^{6+} \&\right.$ total $\left.\mathrm{Cr}\right)$ serves as variable 1st and the depth level of the dumping site were 2 nd variable and the concentration of chromium species is treated as dependent variables. Three hypotheses were proposed as

1. Depth will have no significant effect on the leaching of chromium species, 
2. Chromium species will have no significant effect on the leaching of chromium species $(\mathrm{Cr} 6+\&$ total $\mathrm{Cr}$ ) and

3. Depth and chromium species interaction will have no significant effect on the leaching of chromium species.

The result pointed out a significant effect on depth factor $F(2,12)=37.334, p(0.000)<0.05$ and reject the 1 st hypothesis and explain that there were significant differences in the TCLP concentration of chromium species within the group of different depth at the dumping site. The variable second also indicates a significant effect on Chromium species factor $F(1,12)=9.380, p(0.004)<0.05$ and rejected the 2 nd hypothesis and elucidate that there were significant differences in the TCLP concentration of chromium species within the group $\left(\mathrm{Cr}^{6+} \&\right.$ Total $\mathrm{Cr}$ ). Output of SPSS, $\mathrm{F}(2,12)=3.022, \mathrm{p}(0.099)>0.05$ accepted the hypothesis and explains the interaction of both factors have no significant effect on the TCLP concentration of chromium species.

\section{LSD Post Hoc Tests}

LSD stand for Least Significant Difference means determined the smallest differences in mean value would be statically significant and it does not adjust for the fact through multiple comparisons are made. In a Bivariates ANOVA, the $p$ values defined the difference between groups are significant or not, but it failed to compare with each group such as significance between group 1 and group 2, Group 2 and group 3 , and group 1 and group 3 respectively. The multiple comparisons have been done by LSD Post Hoc Test in the concentration of hexavalent chromium and total chromium in TCLP extract of deferent depth, 6 pairwise comparisons are given in Table 3. The p-value of all the tested groups has been less than 0.05 showing the significant differences in all the comparisons. The leaching behavior of Chromium species in different depths $(0-15 \mathrm{~cm}, 15-75 \mathrm{~cm}$, and $5-150 \mathrm{~cm})$ at duping site is significant means the leaching behavior of Chromium species is higher as well as increasing of depth of dumping site.

\section{Hierarchical cluster analysis (HCA)}

Hierarchical Cluster Analysis is an advanced helpful technique, which pulls together all the objects based on their similarity. HCA was performed using ward linkage with rescaling distance cluster combined as similarity a measure that is offered visually meaningful dendrogram and separate/cluster the groups (Sahu et al. 2018). HCA classifies physicochemical parameters of BCS sludge given in Fig. 3.1, physicochemical parameters clustered into two major groups that two major groups further divided into two sub-groups step by step. In this study, physicochemical parameters of BCS sludge were divided into four clusters, Bulk density (BD), $\mathrm{pH}$, and hexavalent Chromium (TCLP $\mathrm{Cr}^{6+}$ ) grouped in cluster 1, trivalent Chromium (TCLP Cr ${ }^{3+}$ ), total Chromium (TCLP Cr), TDS and EC represent cluster 2. Trivalent Chromium $\left(\mathrm{Cr}^{3+}\right)$, and hexavalent Chromium (TCLP Cr${ }^{6+}$ ) formed cluster 3, while total Chromium was separated the cluster 4 .

The dendrogram of HCA given in Fig. 3.2 represents the visual identity for the concentration of Chromium species at different depth levels in three sampling location. In this dendrogram, the triplicate sample of 
three deferent depth level at the dumping site was divided into two major clusters in which one major cluster is further divided into two sub-clusters; sample 1 and sample 2 at $0-15 \mathrm{~cm}$ depth contributes in sub-cluster 1 , while sample 3 at $0-15 \mathrm{~cm}$ depth formed sub-cluster 2 . The second major cluster was further divided into three sub-cluster; sample 1 and sample 2 at $15-75 \mathrm{~cm}$ depth contribute to sub-cluster 3 at $15-75 \mathrm{~cm}$ depth. Sample 3 at $15-75 \mathrm{~cm}$ depth and sample 2 at $75-150 \mathrm{~cm}$ depth both contributed in sub-cluster 4, while sample 1 at 75-150 cm and sample 3 at $75-150 \mathrm{~cm}$ formed Sub-cluster 5.

\section{Pearson Correlation analysis}

Two tails Bivariates correlation was run through Pearson correlation methods in SPSS to finding the relation between a physicochemical variable of BCS sludge. In this study, statistical correlation analysis was done at 0.05 and 0.01 level which is given in Table 4. The correlation was found significant with total $\mathrm{Cr}^{3+}$ at 0.05 level are pH, EC, TDS, Total $\mathrm{Cr}^{6+}, \mathrm{TCLP} \mathrm{TCr}$, and TCLP Cr${ }^{3+}$. The correlation of TCLP Cr${ }^{6+}$, and TCLP Cr3 + both are significant at 0.05 level with total $\mathrm{Cr}$. The correlation was significant at 0.01 level in EC, TDS, total $\mathrm{Cr}$, total $\mathrm{Cr}^{6+}, \mathrm{TCLP} \mathrm{Cr}^{6+}$, and TCLP Cr${ }^{3+}$ with TCLP TCr. A significant correlation was noted with $\mathrm{TCLP} \mathrm{Cr}^{6+}$ in TCLP Cr${ }^{3+}, \mathrm{EC}$, and TDS at 0.01 level while EC, TDS, total $\mathrm{Cr}^{6+}$, and TCLP Cr have a significant correlation with TCLP $\mathrm{Cr}^{3+}$.

\section{Conclusions}

The present study was executed to the profiling of chromium and its different oxidation species in the chromium-containing hazardous waste collected from the unlined/ illegal waste dumpsite which was situated at 26ه 24'57" NL \& 80ه 3'28" EL in Khanchandpur Kharanja, Rania, Kanpur Dehat, district of Uttar Pradesh, India. Basic Chrome Sulphate Sludge (BCS) was dumped by different industries which were responsible for generating $\mathrm{Cr}$ containing hazardous wastes since 1976 and closed in 2005 by the Government of India. Total 27 samples were collected from the BCS dumping site, 3-3 samples drawn from each depth i.e., Top layer $(0-15 \mathrm{~cm})$, subsurface layer $(15-75 \mathrm{~cm})$, and lower depth $(75-150 \mathrm{~cm}) .$. It was observed that sludge $\mathrm{pH}, \mathrm{EC}$, and TDS were significantly increased on increasing depth which strongly justified the leaching of salts in lower depth. Total $\mathrm{Cr}$ and its different oxidation species were also showed that concentration of $\mathrm{Cr}$ increased on increasing depth and TCLP based concentration was also significantly increased on increasing depth wise-versa similar trend was also observed in total and TCLP hexavalent and trivalent $\left(\mathrm{Cr}^{6+}\right.$ and $\left.\mathrm{Cr}^{3+}\right)$ chromium concentration which showed high leaching tendency of sludge. Bivariates analysis of variance had performed to identifying the leaching characteristic of chromium species in different depth in which chromium species $\left(\mathrm{Cr}^{6+} \&\right.$ total $\mathrm{Cr}$ ) serves as variable Ist which showed a significant effect on depth factor $F(2,12)=37.334, p(0.000)<0.05$, and explain that there are significant differences in the TCLP concentration of chromium species within the group of different depth at the dumping site. Depth level of the dumping site was $2 \mathrm{nd}$ variable which also indicated a significant effect on Chromium species factor $F(1,12)=9.380, p(0.004)<0.05$, and the concentration of chromium species is treated as dependent variables and elucidate that there were 
significant differences in the TCLP concentration of chromium species within the group $\left(\mathrm{Cr}^{6+}\right.$ \& $\mathrm{Total} \mathrm{Cr}$ ). Hierarchical Cluster Analysis (HCA) showed that BD, pH, and TCLP $\mathrm{Cr}^{6+}$ were grouped in cluster 1, TCLP $\mathrm{Cr}^{3+}$, TCLP Cr, TDS, and EC represented cluster 2. $\mathrm{Cr}^{3+}$ and TCLP $\mathrm{Cr}^{6+}$ formed cluster 3 , while total $\mathrm{Cr}$ was separated in cluster 4. A significant correlation was observed with $\mathrm{TCLP} \mathrm{Cr}^{6+}$ in $\mathrm{TCLP} \mathrm{Cr}^{3+}, \mathrm{EC}$, and TDS at 0.01 level while EC, TDS, total $\mathrm{Cr}^{6+}$, and TCLP Cr were significant correlated with $\mathrm{TCLP} \mathrm{Cr}^{3+}$. The leaching behavior of $\mathrm{Cr}$ species was higher as well as increasing of depth in the dumping site. So, it was concluded that BCS sludge required proper treatment, storage, and proper disposal facilities to avoid the contamination of soil and groundwater. Techno-economic feasibility must be explored for chemical treatment (immobilization) of chromium bearing sludge and its judicious disposal in either of two land-fill (TSDF) facilities operational in close proximity at village Khanchandpur Kharanja, Rania, Kanpur Dehat, UP, India.

\section{Declarations}

Acknowledgement: The author was thankful to Director, Bharat Oil and Waste Management Ltd, Kanpur, UP, India for permission to use the lab facility. Author was also appreciated continuous support and suggestion of Dr. R. K. Singh (Scientist E), Regional Director, Central Pollution Control Board, Lucknow.

Competing interest: The author declares no competing interest.

Funding: Authors have not received any fund from any Govt. Department for this study.

\section{References}

1. Adriano DC (1986) Trace Elements in the Terrestrial Environment, Springer, New York, NY, USA.

2. Anderson RA (1995) Chromium and parental nutrition. Nutrition 11: 83-86.

3. Anderson RA (1993) Recent advances in the clinical and biochemical effects of chromium deficiency. Progress in Clinical and Biological Research 380:221-234.

4. Bartlett R J (1991) Chromium cycling in soils and water: links, gaps, and methods. Environment Health Perspecive 92 : 17-24.

5. Blaser P, Zimmermann S, Luster J, Shotyk W (2000) Critical examination of trace element enrichments and depletions in soils: as, $\mathrm{Cr}, \mathrm{Cu}, \mathrm{Ni}, \mathrm{Pb}$, and $\mathrm{Zn}$ in Swiss forest soils. Science of the Total Environment 249 (1-3): 257-280. DOI: 10.1016/s0048-9697(99)00522-7

6. Callahan MA, Slimak MW, Bagel N, and Grevatt, PC (1979) Water-related environmental fate of 129 priority pollutants, vol. II. U.S. EPA, office of water planning and standards, office of water and waste management. Washington, DC. EPA/440/4-79-029.

7. Cary E E, Allaway WH, Olson O E (1977) Control of chromium concentrations in food plants. 1. Absorption and translocation of chromium by plants. Journal of Agricultural and Food Chemistry 25(2):300-304. DOI: 10.1021/jf60210a048 
8. Central Pollution Control Board (2011) Manual of Sampling, Analysis and Characterization of Hazardous wastes, CPCB, Delhi.

9. Chrysochoou M, Sirine C F, Matthew AM, Moon DH, Dermatas D (2009) Microstructural Analyses of $\mathrm{Cr}(\mathrm{VI})$ Speciation in Chromite Ore Processing Residue (COPR). Environmental Science \& Technology 43:5461-5466.

10. Covington AD, Sykes R L (1983) A practical chrome recovery system using magnesium oxide. Journal of the Society of Leather Technologists and Chemists 67(1): 5-12.

11. Deakin D, West L.J, Stewart DI, Yardley BWD (2001) The leaching characteristics of chromite ore processing residue. Environmental Geochemistry and Health 23:201-206. http://doi.org/10.1023/A:1012271330251

12. Dhungana T P, Yadav P. N (2009) Determination of chromium in tannery effluent and study of adsorption of $\mathrm{Cr}(\mathrm{VI})$ on sawdust and charcoal from sugarcane bagasses. Journal of Nepal Chemical Society 23: 93-101. DOI: https://doi.org/10.3126/jncs.v23i0.2102

13. Dreiss SJ (1986) Chromium migration through sludge-treated soils. Ground Water 24(3):312-321.

\section{https://doi.org/10.1111/j.1745-6584.1986.tb01007.x}

14. Ducros V (1992) Chromium metabolism: A literature review. Biological Trace Element Research 32:65-77.

15. Elzinga E J, Cirmo A (2010) Application of sequential extractions and X-ray absorption spectroscopy to determine the speciation of chromium in Northern New Jersey marsh soils developed in chromite ore processing residue (COPR). Journal of Hazardous Materials 183(1-3):145-154.

16. EPA (1984) Health assessment document for chromium. Environmental criteria and assessment office, research triangle park, NC. p1. EPA/600/8-83-014F. NTIS PB 85-115905 Available from National Technical Information Service: Springfield, VA

17. Fishbein $L$ (1981) Sources, transport and alterations of metal compounds: an overview. I. Arsenic, beryllium, cadmium, chromium, and nickel. Environmental Health Perspective 40:43-64. DOI: 10.1289/ehp.814043

18. Földi C, Dohrmann R, Matern K Mansfeldt T (2013) Characterization of chromium-containing wastes and soils affected by the production of chromium tanning agents. Journal of Soils and Sediments 13(7):1170-1179. https://doi.org/10.1007/s11368-013-0714-2

19. François Gagné (2014) Descriptive Statistics and Analysis in Biochemical Ecotoxicology. In François Gagné (Eds.). Biochemical Ecotoxicology (p.p. 209-229). Academic press. DOI: http://dx.doi.org/10.1016/B978-0-12-411604-7.00012-X

20. Geelhoed JS, Meeussen JCL, Hillier S, Lumsdon DG, Thomas RP, Farmer JG, Paterson E (2002) Identification and geochemical modeling of processes controlling leaching of $\mathrm{Cr}(\mathrm{VI})$ and other major elements from chromite ore processing residue. Geochimica et Cosmochimica Acta 66:3927-3942. https://doi.org/10.1016/S0016-7037(02)00977-8

21. Hartford W, Kirk-Othmer (1979) Encyclopedia of Chemical Technology, 3rd ed.; John Wiley and Sons: (Vol. 6), New York. 
22. Kennedy L (1999). Cooperating for survival: tannery pollution and joint action in the Palar Valley (India). World Development 27(9):1673-1691.

23. Kimbrough DE, Cohen Y, Winer AM, Creelman L, Mabuni C, (1999) A critical assessment of chromium in the environment. Critical Reviews in Environmental Science and Technology 29:1-46. https://doi.org/10.1080/10643389991259164

24. Kumar V, Sahu P, Singh PK, Markandeya (2020) Organic and inorganic pollutants in diverse location of Gomti river at Lucknow City; A multivariate statistical approach. International Journal of Environmental Research. https://doi.org/10.1007/s41742-020-00290-1

25. Lasat MM (2002) Phytoextraction of toxic metals: a review of biological mechanisms. Journal of Environmental Quality, 31(1), 109-120.

26. Lund HF (1971) Industrial Pollution Control Handbook. McGrawHill: New York.

27. Makdisi RS (1991) Tannery wastes definition, risk assessment and cleanup options, Berkeley, California. Journal of Hazardous Materials 29(1):79-96.

28. Mandal BK, Vankayala R, Kumar LU (2011). Speciation of Chromium in Soil and Sludge in the Surrounding Tannery Region, Ranipet, Tamil Nadu. ISRN Toxicology 697980:1-10.

29. Martin TD, Martin ER (1989) Evaluation of Method 200.2 Sample Preparation Procedure for Spectrochemical Analyses of Total Recoverable Elements, December 1989, U.S. Environmental Protection Agency, Office of Research and Development, Environmental Monitoring Systems Laboratory, Cincinnati, Ohio 45268.

30. Matern K, Weigand H, Kretzschmar R, Mansfeldt T (2020) Leaching of hexavalent chromium from young chromite ore processing residue. J. Environ. Qual. 49:712-722.

31. Matern K, Weigand H, Singh A, Mansfeldt T (2017) Environmental status of groundwater affected by chromite ore processing residue (COPR) dumpsites during pre-monsoon and monsoon seasons. Environ Sci Pollut Res 24: 3582-3592. https://doi.org/10.1007/s11356-016-8110-2

32. Mohan D, Singh K P, Singh VK (2006) Trivalent chromium removal from wastewater using low cost activated carbon derived from agricultural waste material and activated carbon fabric cloth. Journal of Hazardous Materials 135(1-3):280-295.

33. Nieboer E, Jusys AA (1988) Chromium in the natural and human environments (John Wiley \& Sons, New Yark) 21.

34. Nriagu JO, Nieboer E (1988) Chromium in the Natural and Human Environments; John Wiley and Sons: New York.

35. Palmer CD, Wittbrodt PR (1991) Processes Affecting the Remediation of Chromium-Contaminated Sites. Environmetal Health Perspective 92:25-40. doi: 10.1289/ehp.919225

36. Pendias K, Pendias H (1992) Trace Elements in Soils and Plants, CRC Press, Boca Raton, Fla, USA.

37. Raju M, Tandon SN (1999) Operationally determined speciation of chromium in tannery sludges. Chemical Speciation and Bioavailability 11(2): 67-70. 
38. Richard FC, Bourg ACM (1991) Aqueous geochemistry of chromium: a review. Water Research 25:807-816.

39. Sahu P, Kisku GC, Singh PK, Kumar V, Kumar P, Shukla N (2018) Multivariate statistical interpretation on seasonal variations of fluoride-contaminated groundwater quality of Lalganj Tehsil, Raebareli District (UP), India. Environmental Earth Science, 77, 484. https://doi.org/10.1007/s12665-018-76581

40. Shriver DF, Atkins PW, Langford CH (1994) Inorganic chemistry (2nd ed.). Oxford: Oxford University Press.

41. Silveira ML, Alleoni LRF, O'Connor GA, Chang AC (2006) Heavy metal sequential extraction methodsA modification for tropical soils. Chemosphere 64(11): 1929-1938.

https://doi.org/10.1016/j.chemosphere.2006.01.018

42. Singh RK, Sachan VK, Ansari MQ, Pandey DS and Kamyotra JS (2013) Groundwater Pollution due to chromium rich hazardous waste disposal in Rania-Khanchandpur area, district Kanpur Dehat (R), U.P., India: A case study. Water and Biodiversity, 11-16.

43. Singh M, Tapadia K, Jhariya D, Sahu P (2021) Evaluation of uranium containing ground water quality and non-carcinogenic risk assessment in inhabitant of Bijapur District of Chhattisgarh, Central India. Journal of Radioanalytical Nuclear Chemistry 327:939-947. https://doi.org/10.1007/s10967-02007572-0

44. Siraj S, Islam M, Das PC, Masum S, Jahan I A, Ahsan A, Shajahan M D (2012) Removal of chromium from tannery effluent using chitosancharcoal composite. Journal of the Bangladish Chemical Society 25(1): 53-61.

45. Tessier A, Campbell PGC, BIsson M (1979) Sequential extraction procedure for the speciation of particulate traces metals. Analytical Chemistry 51(7): 844-851. https://doi.org/10.1021/ac50043a017

46. USEPA (1998) Toxicological Review of hexavalent chromium. CAS No. 18540-29-9, U.S. Envoronment Protection Agency, Washington, DC.

47. USEPA (1998) Test Method: Soil and Waste pH(SW-845;9045D).

48. USEPA (1998) Method 1311 Toxicity Characteristic Leaching Procedure (SW-846; 9045D).

49. Wang XP, Shan XQ, Zhang SZ, Wen B (2004) A model for evaluation of the phytoavailability of trace elements to vegetables under the field conditions. Chemosphere 55(6): 811-822. https://doi.org/10.1016/j.chemosphere.2003.12.003

\section{Tables}


Table-1: Physicochemical characterization of Leachates extracted from soil sample collected from different depth and different locations of dumping site of Khanchandpur Kharanja, Rania, Kanpur Dehat district of Uttar Pradesh, India.

\begin{tabular}{|c|c|c|c|c|c|c|c|c|c|c|c|}
\hline \multicolumn{2}{|c|}{ Depth $(\mathrm{cm})$ Location } & $\begin{array}{l}\text { Bulk Density } \\
\text { (gmcc-1) }\end{array}$ & $\mathrm{pH}$ & $\begin{array}{c}\mathrm{EC} \\
\left(\mathrm{dSm}^{-1}\right)\end{array}$ & $\begin{array}{l}\text { TDS } \\
\left(\mathrm{mgkg}^{-1}\right)\end{array}$ & $\begin{array}{l}\text { Total } \mathrm{Cr} \\
\left(\mathrm{mgkg}^{-1}\right)\end{array}$ & $\begin{array}{l}\text { Total } \mathrm{Cr}^{+} \\
\left(\mathrm{mgkg}^{-1}\right)\end{array}$ & $\begin{array}{l}\text { Total } \mathrm{Cr}^{3+} \\
\left(\mathrm{mgkg}^{-1}\right)\end{array}$ & \multicolumn{2}{|c|}{ TCLP Total $\mathrm{Cr}$ TCLP $\mathrm{Cr}^{6+}$} & $\begin{array}{r}\text { TCLP Cr }{ }^{3+} \\
\left(\mathrm{mgkg}^{-1}\right)\end{array}$ \\
\hline \multirow[t]{5}{*}{$0-15$} & L1 & 0.99 & 10.16 & 950 & 630 & 26037.74 & 10990.34 & 4080.23 & 228.36 & 113.82 & 91.46 \\
\hline & L 2 & 1.08 & 11.1 & 860 & 565 & 27557.33 & 10662.62 & 8307.04 & 294.64 & 127.67 & 166.97 \\
\hline & L3 & 1.08 & 11.9 & 995 & 600 & 25029.94 & 7306.54 & 14466.45 & 126.32 & 83.8 & 42.51 \\
\hline & Mean & 1.05 & 11.05 & 935 & 598.33 & 26208.34 & 9653.17 & 8951.24 & 216.44 & 108.43 & 100.31 \\
\hline & SEM & 0.03 & 0.5 & 39.69 & 18.78 & 734.56 & 1177.12 & 3015.5 & 48.95 & 12.95 & 36.2 \\
\hline \multirow[t]{5}{*}{$15-75$} & L1 & 1.04 & 10.77 & 1740 & 1250 & 34308.46 & 21957.51 & 15064.77 & 309.24 & 136.9 & 195.42 \\
\hline & $\mathrm{L} 2$ & 1.09 & 11.78 & 2640 & 1785 & 34515.18 & 26208.14 & 16894.71 & 464 & 190 & 274 \\
\hline & L3 & 1.11 & 10.88 & 1625 & 1170 & 39482.59 & 25016.14 & 17723.44 & 45.52 & 132.29 & 211.65 \\
\hline & Mean & 1.08 & 11.14 & 2001.67 & 71401.67 & 36102.08 & 24393.93 & 16560.96 & 406.25 & 153.06 & 227.02 \\
\hline & SEM & 0.02 & 0.32 & 320.89 & 193.05 & 1691.31 & 1265.88 & 785.41 & 48.8 & 18.52 & 23.95 \\
\hline \multirow[t]{5}{*}{$75-150$} & L1 & 0.97 & 11.81 & 3100 & 2085 & 42504.97 & 27440.22 & 3318.12 & 655.04 & 253.83 & 511.21 \\
\hline & L2 & 1.12 & 11.9 & 3520 & 2350 & 44835.82 & 27327.44 & 17508.38 & 518.56 & 227.71 & 300.85 \\
\hline & L3 & 1.00 & 11.64 & 2690 & 1815 & 41094.53 & 20073.61 & 21020.92 & 379.2 & 233.87 & 246.91 \\
\hline & Mean & 1.03 & 11.78 & 3103.33 & 32083.33 & 42811.77 & 24947.08 & 20615.81 & 517.6 & 238.47 & 352.99 \\
\hline & SEM & 0.05 & 0.08 & 239.61 & 154.44 & 1090.86 & 2436.95 & 1689.32 & 79.63 & 13.65 & 80.63 \\
\hline
\end{tabular}

Notes: L-1: Towards the NH-2; L-2: Mid of Dump site, L-3: Hind of dump site. SEM-Standard Error mean 
T able 2. Bivariates analysis of variance to indentifying the leaching characteristic of chromium species in TCLP Extract of different depth at dumpling site

\begin{tabular}{|c|c|c|c|c|c|}
\hline Source & Type III Sum of Squares & \multirow{2}{*}{$\begin{array}{l}\text { df } \\
5\end{array}$} & \multirow{2}{*}{$\begin{array}{l}\text { Mean Square } \\
74066.523\end{array}$} & \multirow{2}{*}{$\begin{array}{l}\text { F Sig } \\
12.670\end{array}$} & \multirow[b]{2}{*}{0.000} \\
\hline Corrected Model & $370332.616 a$ & & & & \\
\hline Intercept & 1345220.966 & 1 & 1345220.966 & 230.122 & 0.000 \\
\hline Depth & 205011.254 & 1 & 205011.254 & 35.071 & $0.000 *$ \\
\hline Cr Species & 139805.277 & 2 & 69902.638 & 11.958 & $0.001^{*}$ \\
\hline \multicolumn{6}{|l|}{$(\mathrm{Cr} 6+\&$ Total $\mathrm{Cr})$} \\
\hline Depth * Cr Species & 25516.085 & 2 & 12758.043 & 2.182 & 0.155 \\
\hline Error & 70148.147 & 12 & 5845.679 & & \\
\hline Total & 1785701.730 & 18 & & & \\
\hline Corrected T otal & 440480.764 & 17 & & & \\
\hline
\end{tabular}

\footnotetext{
a. Tests of Between-Subjects Effects: TCLP Concentration of Cr6+\& Cr3+ (Depth Wise)

b. Dependent Variable: Concentration of $\mathrm{Cr} 6+\& \mathrm{Cr} 3+$
}

Table 3. Multiple Comparisons of LSD Post Hoc T ests for leaching characteristic of chromium species in TCLP Extract of different depth at dumpling site

\begin{tabular}{llllll}
\hline Depth & Depth & Mean Difference & Sig. & \multicolumn{2}{l}{$95 \%$ Confidence Interval } \\
(A) & (B) & (A-B) & & Low er Bound & Upper Bound \\
\hline $0-15 \mathrm{~cm}$ & $15-75 \mathrm{~cm}$ & $-117.2233^{*}$ & $0.021^{*}$ & -213.4016 & -21.0451 \\
& $75-150 \mathrm{~cm}$ & $-215.6000^{*}$ & $0.000^{*}$ & -311.7782 & -119.4218 \\
& & & & & \\
$15-75 \mathrm{~cm}$ & $0-15 \mathrm{~cm}$ & $117.2233^{*}$ & $0.021^{*}$ & 21.0451 & 213.4016 \\
& $75-150 \mathrm{~cm}$ & $-98.3767^{*}$ & $0.046^{*}$ & -194.5549 & -2.1984 \\
$75-150 \mathrm{~cm}$ & $0-15 \mathrm{~cm}$ & $215.6000^{*}$ & $0.000^{*}$ & 119.4218 & 311.7782 \\
& $15-75 \mathrm{~cm}$ & $98.3767^{*}$ & $0.046^{*}$ & 2.1984 & 194.5549 \\
\end{tabular}

\footnotetext{
*. The mean difference is significant at the 0.05 level. Concentration was taken as dependent variable for all depth.
} 
Table 4. Pearson Correlation analysis in physicochemical profiling of Basic Chrome Sulphate sludge at dumping site

\begin{tabular}{|c|c|c|c|c|c|c|c|c|c|c|}
\hline & Bulk Density & $\mathrm{pH}$ & $\mathrm{EC}$ & TDS & Total $\mathrm{Cr}$ & Total $\mathrm{Cr}^{6+}$ & Total $\mathrm{Cr}^{3+}$ & TCLP T Cr & TCLP $\mathrm{Cr}^{6+}$ & TCLP Cr ${ }^{3+}$ \\
\hline Bulk Density & 1 & & & & & & & & & \\
\hline $\mathrm{pH}$ & 0.229 & 1 & & & & & & & & \\
\hline $\mathrm{EC}$ & -0.027 & 0.626 & 1 & & & & & & & \\
\hline TDS & -0.025 & 0.589 & $0.998 * *$ & 1 & & & & & & \\
\hline Total $\mathrm{Cr}$ & 0.016 & 0.423 & $0.894 * *$ & $0.913 * *$ & 1 & & & & & \\
\hline Total Cr6+ & 0.095 & 0.319 & $0.846 * *$ & $0.876 * *$ & $0.892^{* * *}$ & 1 & & & & \\
\hline Total Cr3+ & -0.047 & $0.700^{*}$ & $0.770^{*}$ & $0.777 *$ & $0.806 * *$ & $0.724 * 1$ & & & & \\
\hline TCLP TCr & -0.075 & 0.388 & $0.834 * *$ & $0.848 * *$ & $0.861 * *$ & $0.898 * *$ & $0.694^{*}$ & 1 & & \\
\hline TCLP Cr6 + & 0.051 & 0.421 & $0.800 * *$ & $0.803 * *$ & $0.736^{*}$ & 0.624 & 0.512 & 0.547 & 1 & \\
\hline TCLP Cr3+ & -0.276 & 0.441 & $0.812^{* * *}$ & $0.820 * *$ & $0.794 *$ & $0.807 * *$ & $0.727^{*}$ & $0.958^{* *} *$ & 0.482 & 1 \\
\hline
\end{tabular}

${ }^{*}$ Correlation is significant at the 0.05 level (2-tailed). ${ }^{*}$ Correlation is significant at the 0.01 level (2-tailed).

\section{Figures}

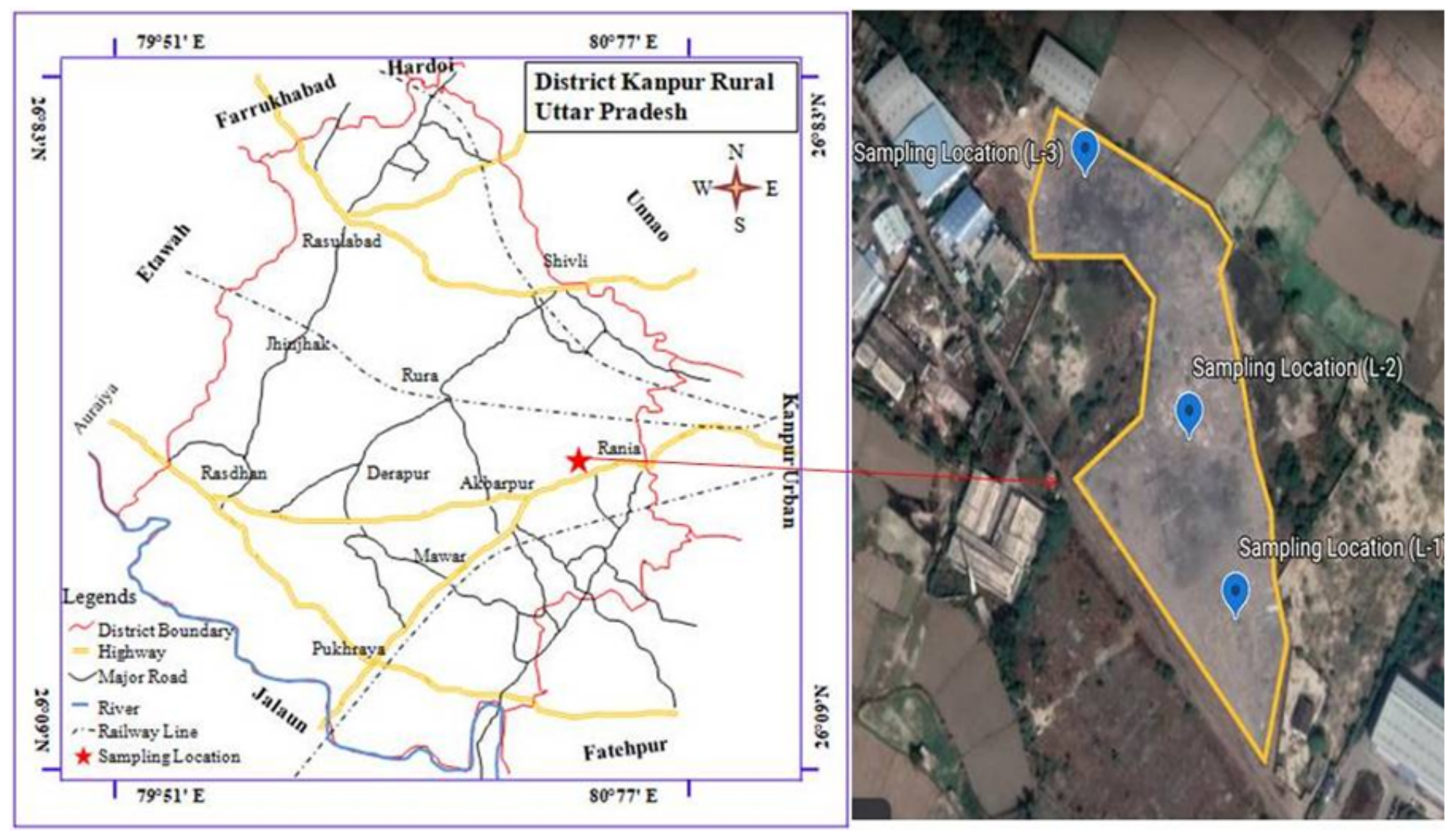


Figure 1

Geographical representation of sampling point at BCS sludge dumping site of Khanchandpur Kharanja, Rania, Kanpur Dehat, U.P., India.

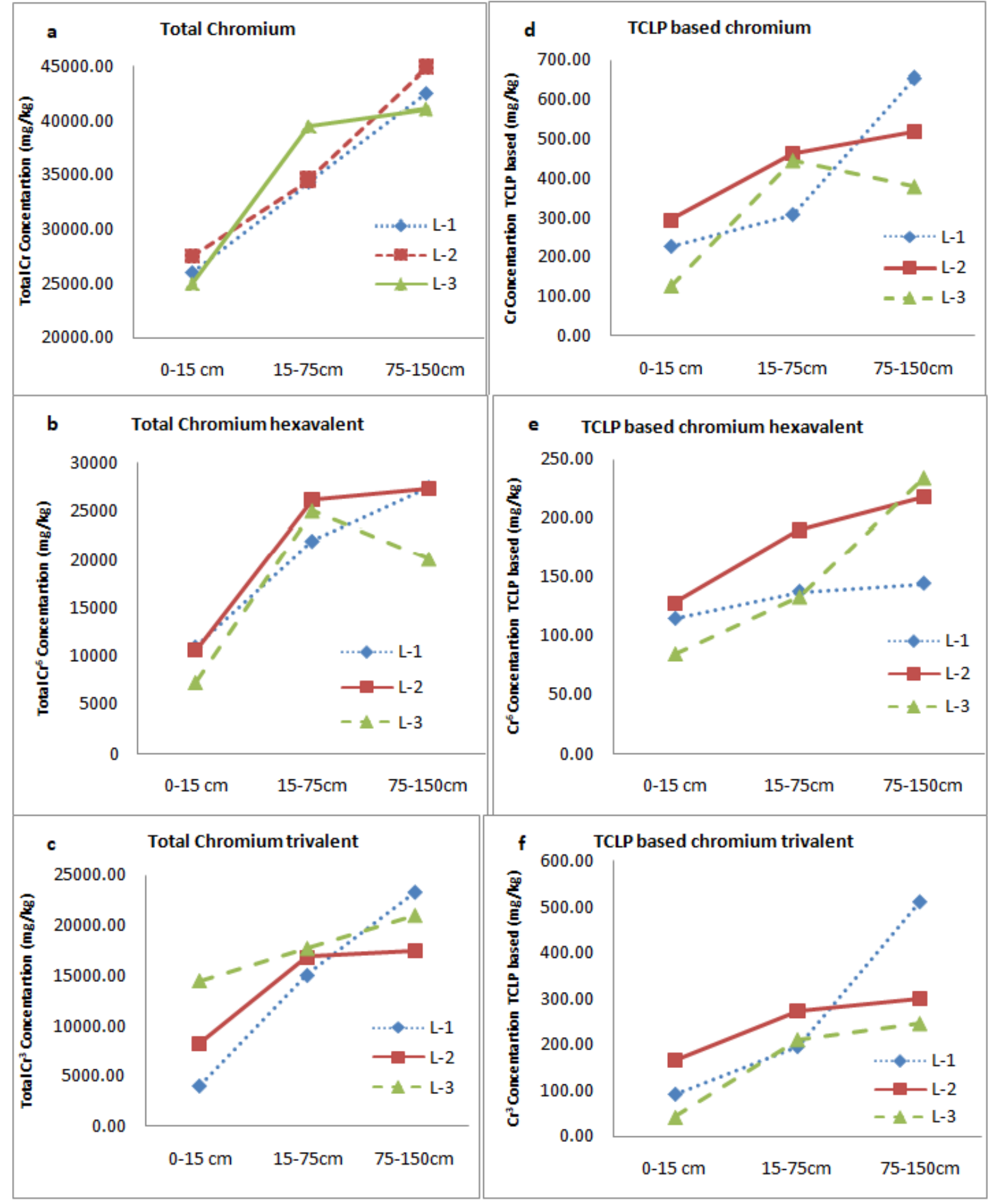

Figure 2 
Comparative study of different oxidation state of chromium species (e.g. $\mathrm{Cr}, \mathrm{Cr}+3$ and $\mathrm{Cr}+6)$ as total and TCLP based concentration in dump site waste.

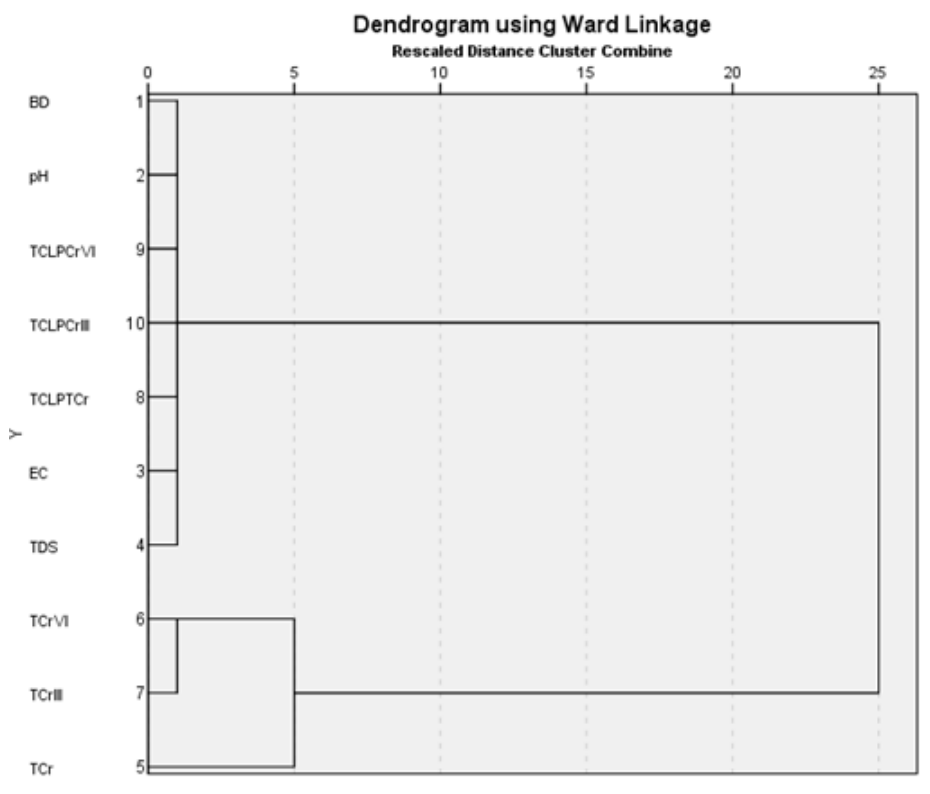

3.1

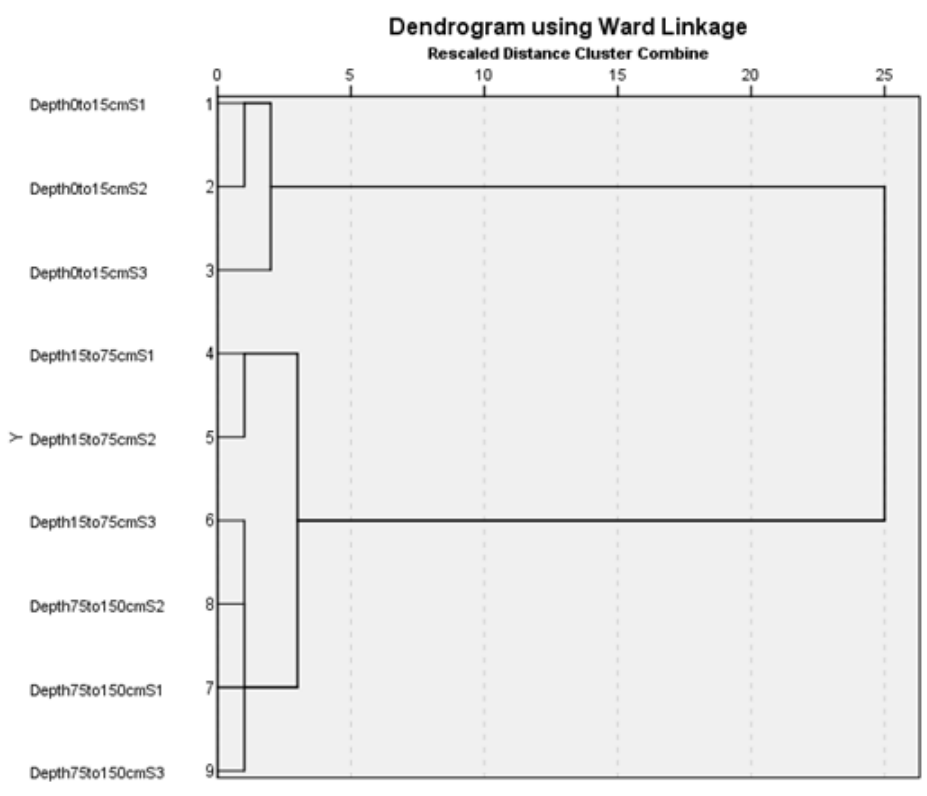

3.2

\section{Figure 3}

Dendrograph of Cluster analysis, 3.1 the measurement of similarity/dissimilarity in Physicho-chemical profiling of BCS Sludge and 3.2 the measurement of similarity/dissimilarity in Chromium species at deferent depth of BCS Sludge dumping site. 